\title{
Changes of cuticular structures of Ischnodemus caspius (Heteroptera: Lygaeoidea: Blissidae) from the fifth instar to the adult
}

\author{
Huai-jun Xue and Wen-jun Bu
}

\begin{abstract}
Xue, H. \& Bu, W. 2007: Changes of cuticular structures of Ischnodemus caspius (Heteroptera: Lygaeoidea: Blissidae) from the fifth instar to the adult. — Entomol. Fennica 18: 218-225.

The fine cuticular structures of adult and 5th instar nymph of Ischnodemus caspius Jakovlev 1871 (Heteroptera: Lygaeoidea: Blissidae) are described, compared and illustrated using 32 SEM photos. The cuticular structures of I. caspius go through great changes during the metamorphosis from the 5th-instar nymph to the adult. The cuticular morphology of the nymph is much more complicated than that of the adult, especially the abdomen, but the long hairs on body of nymph are much more sparse and simple than those of the adult. This study will stimulate further investigations on the development and systematics of Blissidae.

Huai-jun Xue, Institute of Entomology, College of Life Sciences, Nankai University, Tianjin 300071, China; Institute of Zoology, Chinese Academy of Sciences, Beijing 100101, China; E-mail: xue@ioz.ac.cn

Wen-jun Bu (corresponding author), Institute of Entomology, College of Life Sciences, Nankai University, Tianjin 300071, China; E-mail: wenjunbu (a)nankai.edu.cn
\end{abstract}

Received 28 July 2006, accepted 16 March 2007

\section{Introduction}

The family Blissidae is an economically important group, collectively called chinch bugs. It has been previously treated as a subfamily of Lygaeidae (sensu lato), with about 50 genera and 385 species (Schuh \& Slater 1995). Based on a cladistic analysis, Henry (1997a) gave the subfamily Blissinae family status as part of a hierarchical scheme recognizing 15 families in the superfamily Lygeioidea.

Many authors, such as Decker \& Andre (1938), Putshkov (1958), Slater et al. (1969), Slater \& Wilcox (1973), Baranowski (1979), Slater (1974, 1987), Slater \& Brailovsky (1983, 1986, 1990) and Péricart (1998) have described or otherwise treated the nymphs of Blissidae. However, most taxonomic work focuses on adults; Slater \& Harrington (1970) illustrated the fine pruinose area on pronotum of adult Ischnodemus ocbripes (Stål) and discussed its possible function. But descriptions of the fine cuticular structures of nymphal Blissidae are lacking in the literature.

In this study, Ischnodemus caspius Jakovlev, 1871 is chosen as a model species, the fine cuticular structures of its 5th-instar nymphs and adults are compared and illustrated with micrographs. We hope that this study stimulate further investigations on the development and systematics of Blissidae. 


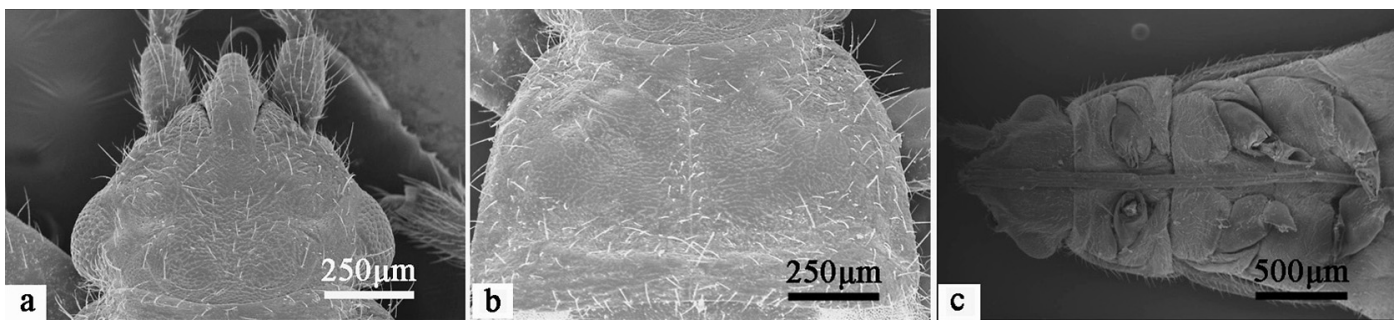

Fig. 1. General view of 5th instar Ischnodemus caspius. - a. Head, dorsal. - b. Pronotum, dorsal. - c. Head and thoracic segments, ventral.
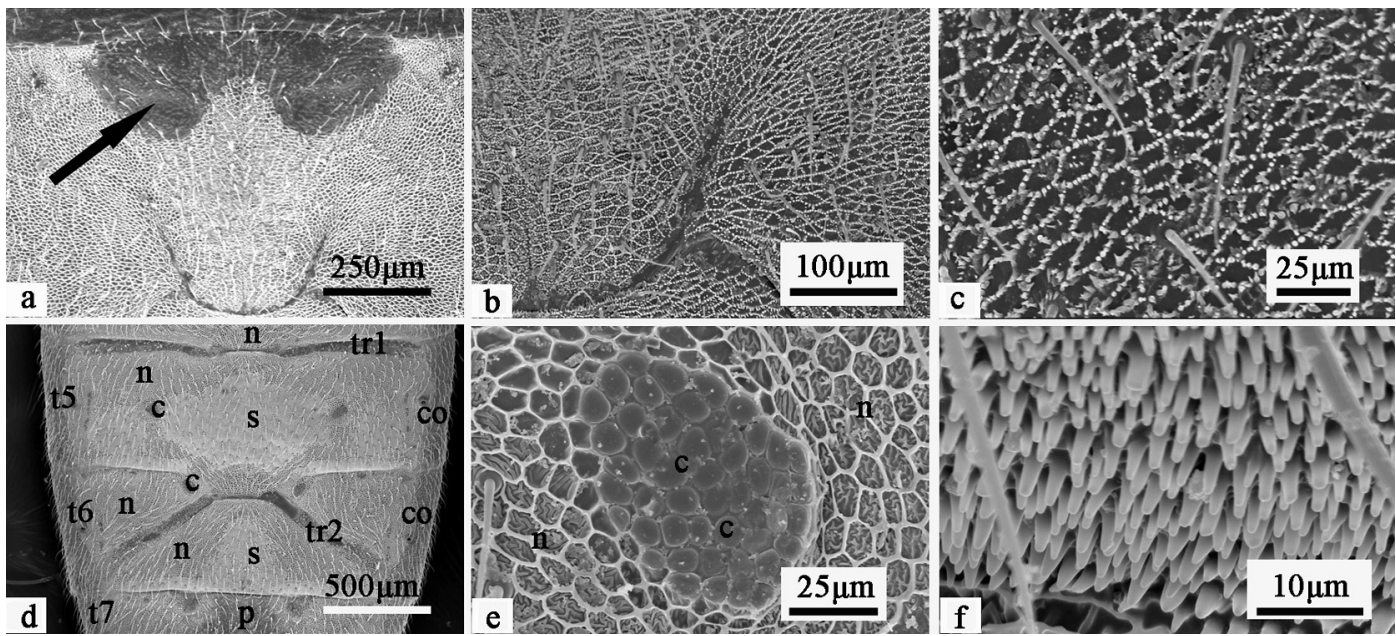

Fig. 2. Detailed view of 5th instar I. caspius, dorsal view. - a. Scutellum (the arrow showing a smooth dumbbelllike area). - b. Scutellum (part) and mesothoracic wing-pad (part). - c. Mesothoracic wing-pad (part). - d. 5th 7th terga of abdomen ( $c=$ cell area; $s=$ spine area; $n=$ network area; $c o=$ cone area; $p=$ protuberance and rugosity area; $5=5$ th tergum; t6=6th tergum; $7=7$ th tergum; tr $1=$ trough-like channel between terga 4 and 5 ; tr2= trough-like channel on tergum 6. - e. Abdomen (part), showing cell area on abdomen (c = cell area; $\mathrm{n}=$ network area). $-\mathrm{f}$. Abdomen (part), showing the spine area.

\section{Materials and methods}

\subsection{Materials}

This study was based on the following specimens: Ischnodemus caspius Jakovlev, 1871 (adults 13 저 5 우 and 15 nymphs of 5thinstar), Seman, Shufu County, Xinjiang Autom. Reg., China, 2002.VIII.17, Qiang Xie, Yun Lü and Yun-ling Ke leg. All specimens are deposited in the Institute of Entomology, College of Life Sciences, Nankai University, Tianjin, China.

\subsection{Methods}

The specimens were prepared for SEM observa- tion modified from Cassier et al. (1994) and da Rosa et al. (1999). Specimens were stored in 70\% ethyl alcohol, transferred into distilled water and cleaned by an ultrasound apparatus. Afterward, they were gradually dehydrated in $70 \%, 95 \%$ and $100 \%$ ethyl alcohol for 2 hours respectively, dried at room temperature for 20 minutes, and placed in a drying oven at $40^{\circ} \mathrm{C}$ for 1 hour. Samples were then fixed to the metallic supports using doublesided sticky tape and coated with a Hitachi E1010 ion sputter apparatus.

Digital images of morphological characters were observed and captured using a scanning electron microscope (S-3500N Hitachi) operated at 15 or $20 \mathrm{kV}$. 


\section{Results}

\subsection{5th-instar nymph of Ischnodemus caspius}

\subsubsection{Dorsal side}

Head, pronotum and basal part of scutellum (a dumbbell-like area) are almost smooth, covered with sparse, thick hairs (Figs. 1a, 1b, 2a). Distal part of scutellum, mesothoracic wing-pads and metathoracic wing-pads (exposed part) have many spine-like structures (Figs. 2a, 2b). The spine-like structures form irregular barrier-like shapes, sometimes with spine-like protuberances in "barriers" (Fig. 2c).

The structures of the abdominal dorsum are much complicated and can be divided into five types (Fig. 2d):

I. "Cell" area. This type of area is composed of a few (several to several dozen) oval cell-like plates, that are slightly depressed (Figs. 2d, 2e). There are 28 "cell" areas located symmetrically along the middle line of the abdomen and surrounded by network areas.

II. "Spine" area. This type of area is made up of dense spine-like structures, similar to those on scutellum and wing-pads. The minute "spines" are distributed more densely, and the tips of them are blunt and smooth (Fig. 2f). This type of area is widely distributed (Fig. 2d), mostly on the middle part of terga 2-6.

III. "Network" area. This type of area is made up of many small grids (e. g. Figs. 2d, 2e, 3a, 3b). Some of the grids are ornamented with irregular, ridge-like structures in the cavities (Fig. 3b) whereas others lack ornaments. This type area is also widely distributed (Figs. 2d, 3a). The areas

Fig. 3. Detailed view of 5th instar I. caspius, dorsal view. - a. Abdomen (part), showing dorsal abdominal scent gland openings between terga 5-6 and the neighboring areas ( $\mathrm{s}=$ spine area; $\mathrm{n}=$ network area; $\mathrm{o}=$ opening; $\mathrm{t} 5=5$ th tergum; $\mathrm{t} 6=6$ th tergum; $\mathrm{tr} 2=$ trough-like channel on tergum 6). - b. Abdomen (part), showing the network area. - c. Abdomen (part), showing the cone area. $-d$. 7 th tergum of abdomen (part), showing the protuberance and rugosity area ( $\mathrm{s} £^{1} 1 / 2$ spine area; $\mathrm{p}=$ protuberance and rugosity area; t6=6th tergum; $7=7$ th tergum). surrounding scent gland openings and near both sides of the trough-like sutures (deep channels jointed with scent gland openings) all belong to this type.

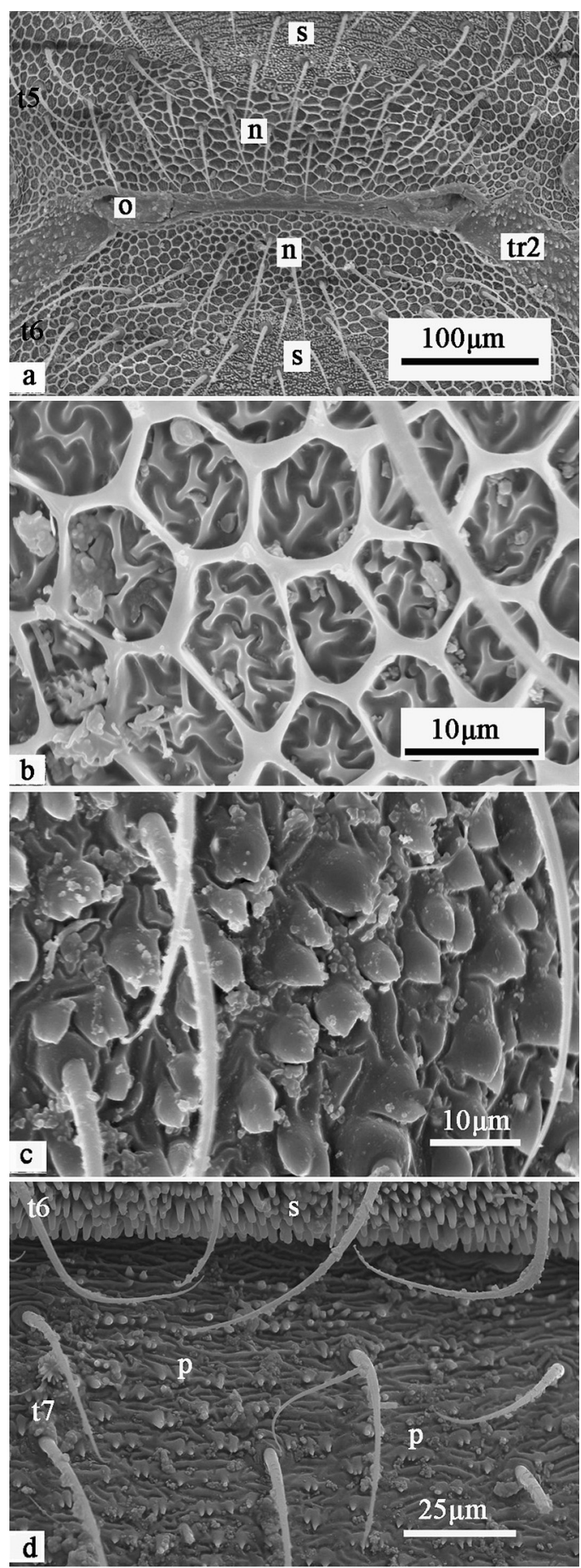




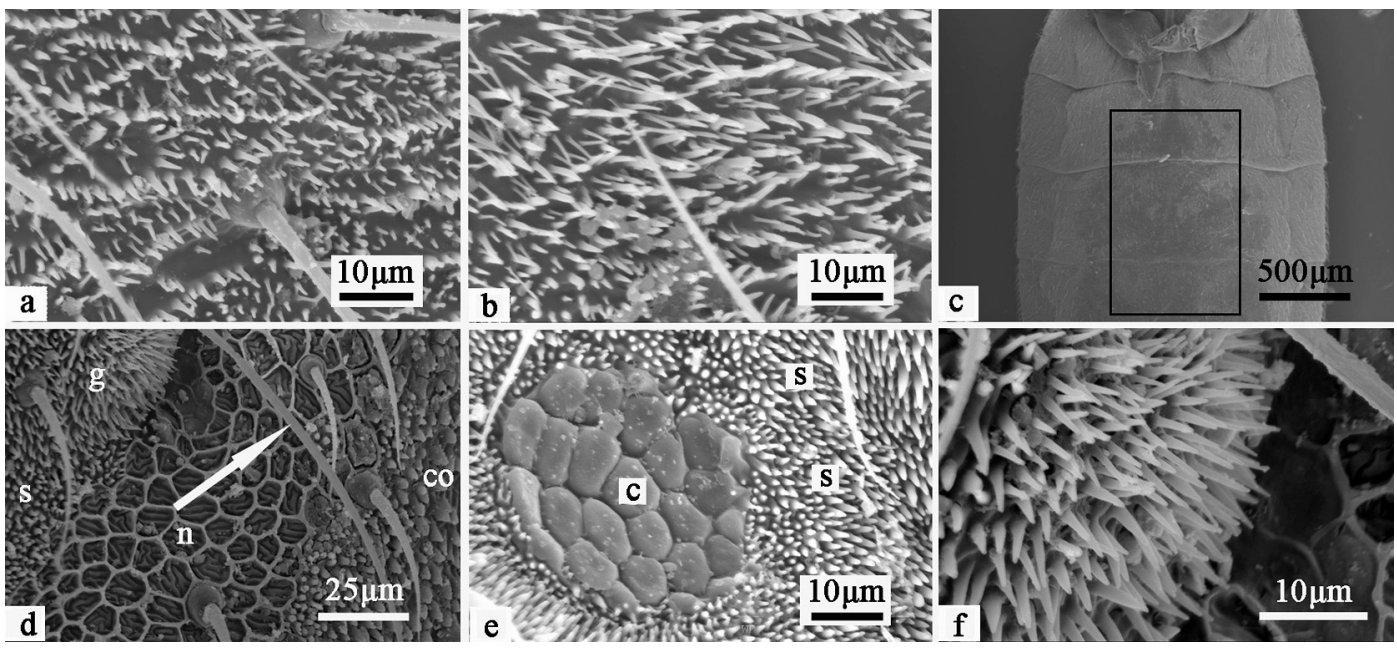

Fig. 4. Detailed view of 5th instar I. caspius, ventral view. - a. Mesothoracic segment (part), showing the small hairs. - b. Metathoracic segment (part), showing the small hairs. - c. Abdomen (part), showing the central bare area (in the frame). $-\mathrm{d}$. Abdomen (part) ( $\mathrm{s=spine}$ area; $\mathrm{n}=$ network area; $\mathrm{co}=$ cone area; $\mathrm{g}=$ trichobothrium area; the arrow showing trichobothria seta). - e. Abdomen (part), showing the cell area (c= cell area; $s=$ spine area). f. Trichobothrium area.

IV. "Cone" area. This type of area covered with short, cone-shaped protuberances on the surface (Fig. $3 \mathrm{c}$ ). These areas are found along the lateral edges of abdomen (Fig. 2d).

V. "Protuberance and rugosity" area. The structure of this type is similar to that of the "cone" area, but possesses many more rugosities on the surface, and the protuberances are very small (Figs. 2d, 3d). These structures are found on the central part of tergum 7 and most of terga 8 and 9.

In addition, a few sparse thick setae are present on the "spine", "cone", "network", and "protuberance and rugosity" areas.

There are two pairs of dorsal abdominal scent gland openings present between terga 4-5 and 56 in this species (and in all Blissidae). The suture between terga 4-5 is straight and horizontal for the whole length, with the portion lateral to openings trough-like (Fig. 2d). The suture between terga $5-6$ is slightly pushed backward and straight, with the portion lateral to the opening of normal intersegmental type not trough-like. However, there is another shallow trough-like channel (on tergum 6) extending postero-laterally from the opening (Figs. 2d, 3a).

\subsubsection{Ventral side}

The cuticular morphology of head and thoracic segments is uniform. Almost all of this "spinelike" area (Figs. 1c, 4a, 4b) is similar to that on the dorsum with some sparse thick hairs.

The structures of ventral side of abdomen are much more complicated and can be divided to six types:

"Cell" area (16 patches in total, located symmetrically along the middle line of the abdomen, surrounded by "spine" area on ventral side, Fig. 4e), "spine" area (present between the "central bare" area and "sub-edge network" area, Fig. 4d), "network" area (these areas border both subedges of the abdomen, Fig. 4d) and "cone" area (these areas border both edges of abdomen, Fig. 4d) are similar to those on dorsal side.

"Protuberance and rugosity" areas are not found, however, other two types of structure are present on ventral side:

"Central bare" area, which is smooth, nearly bare, with only some sparse, thick hairs. This area borders the central part of abdomen (Fig. 4c).

"Trichobothrium" area, where the "spines" surrounding trichobothria are longer than "spines" in other areas (Figs. 4d, 4f). 


\subsection{Adult of Ischnodemus caspius}

Changes of cuticular structures of $I$. caspius Jakovlev from 5 th instar to adult are great. Only the cell areas of larvae are developed also in the adults.

\subsubsection{Dorsal side}

Head, pronotum, scutellum and mesothoracic wings (clavus and corium) are covered with sparse, thick hairs and dense, irregular small hairs (Figs. 5a, 6a, 6b, 6c). However, the small hairs on wings are somewhat especial in shape with their bases heavily swollen (Fig. 6c). Four "black sclerotized plates" are present on dorsal side of head (Figs. 5a, 6a). Two of them are present on the inner side of eyes and two near the basal margin of head. The "black sclerotized plates" seem similar to the "cell" areas on the abdomen of nymphs.

Dense and long hairs are situated almost uniformly on dorsal side of abdomen (Fig. 6d). The number and locality of "cell" areas on abdomen are similar to these found on nymphs. Those areas are bare when observed under optical microscope. But the "cells" are not as clear as those of nymphs (Fig. 6e) observed by SEM.

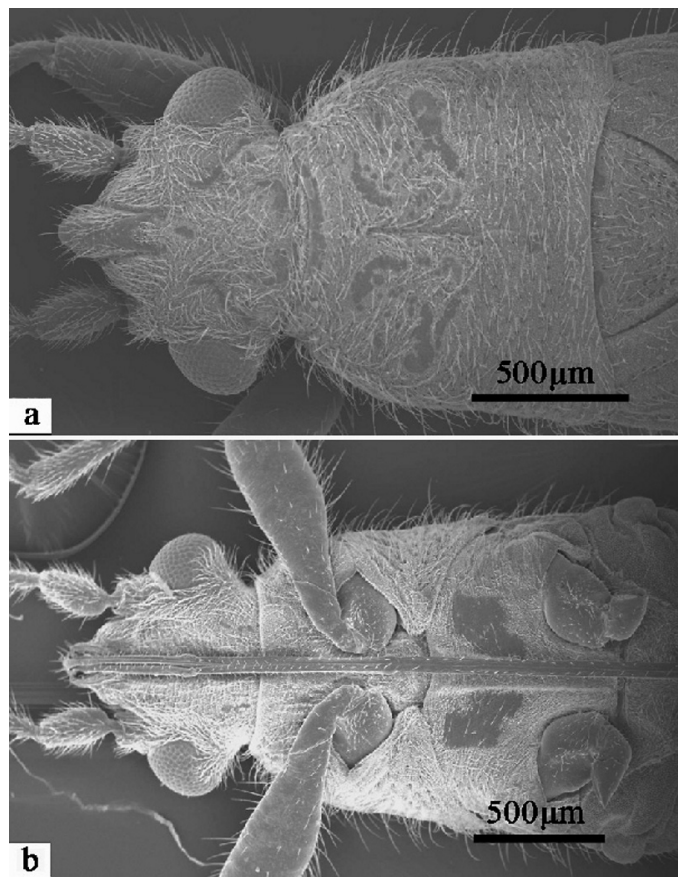

Fig. 5. General view of the head and thoracic segments of the adult of $I$. caspius. - a. dorsal. $-b$. ventral.

As in other species of Heteroptera, only some rugosities (scars) are left on the position of pores of dorsal abdominal scent gland (Fig. 6f) in adult,
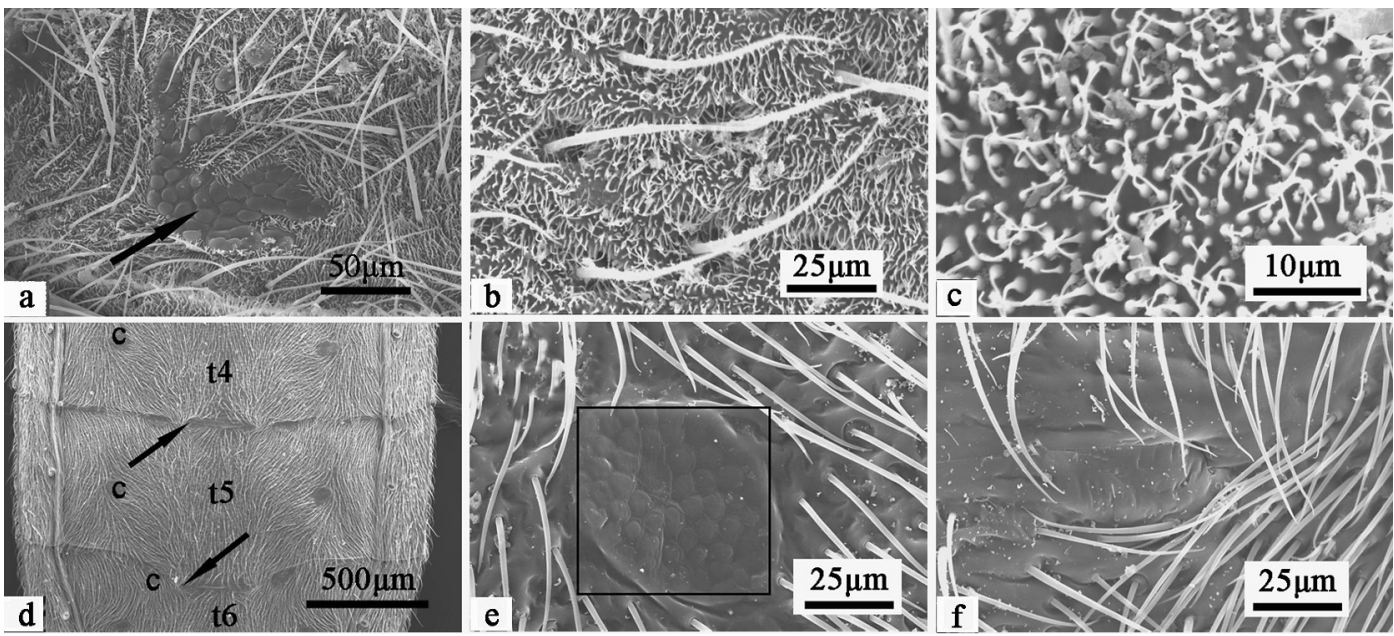

Fig. 6. Adult of $I$. caspius, dorsal view. - a. Head (part), showing the hairs and cell area (the arrow showing cell area). - b. Pronotum (part), showing the hairs. - c. Mesothoracic wings (part), showing the hairs. - d. 4th-6th terga of abdomen ( $c=$ cell area; $t 4=4$ th tergum; $t 5=5$ th tergum; $t 6=6$ th tergum, the arrows showing the scar of dorsal abdominal scent gland openings). - e. Abdomen (part), showing the cell aera (in the frame). $-\mathrm{f}$. Scar of right dorsal abdominal scent gland opening between terga $5-6$. 


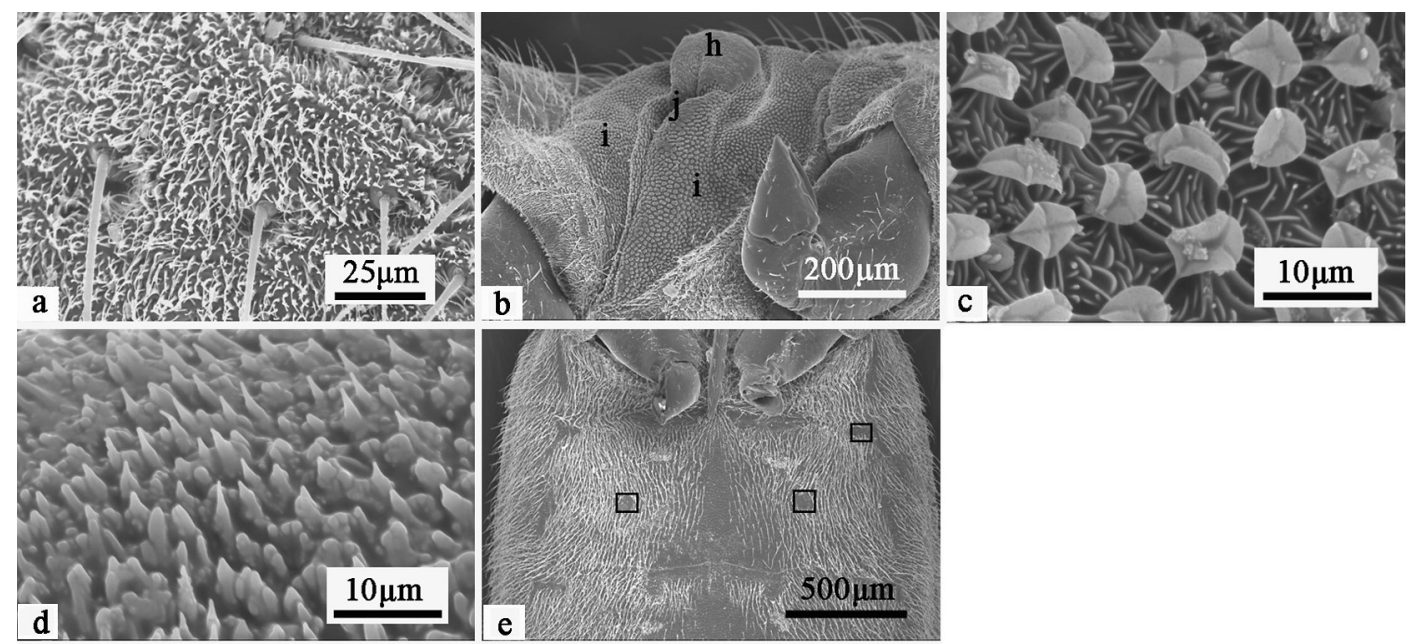

Fig. 7. Adult of $I$. caspius, ventral view. - a. Mesothoracic segment (part), showing the hairs. - b. Metathoracic segment, showing the evaporative area and scent channel ( $\mathrm{h}=a$ pical area of scent channel; i=evaporative area; j= opening of scent gland). - c. Evaporative area. $-d$. Apical area of scent channel. - e. Abdomen (part) (frame showing cell area).

and there are no network structures around the scars as in nymph.

\subsubsection{Ventral side}

The prothoracic and mesothoracic segments have both sparse, thick hairs and dense, small hairs (Figs. 5b, 7a).

Most of the metathoracic segment is occupied by the evaporative area of scent glands (Fig. 7b). Strong differences were observed between the ostiolar evaporative area and the apical area of scent channel. A broad leaf-like framework and thin ridge-like framework can be seen on the former (Fig. 7c), and many irregular protuberances can be seen on the latter when viewed under higher magnification (Fig. 7d).

Uniformly long dense hairs are situated on ventral side of abdomen except on the central part (Fig. 7e). The "cell" areas on abdomen are bare and their shape is not as clear when observed under an optical microscope as those of nymph observed by SEM (Fig. 4e). The number and locality of "cell" areas on abdomen are similar in 5thinstar nymphs and adults.

\section{Discussion}

A number of workers (Putshkov 1958, Baranowski 1979, Slater \& Brailovsky 1983, 1986, 1990, and others) have observed the dark plates situated on the dorsal and ventral surfaces of blissid nymphs, but almost all of them simply used them in taxon identification. Putshkov (1958) called them "black dots" and Slater \& Wilcox (1973) set up a code system for the dark plates for the identification of nymphal Blissidae, which was followed by Slater (1974, 1987), Baranowski (1979) and Slater \& Brailovsky (1983, 1986, 1990).

Several types of dark plates are present on the dorsal side of the abdomen in I. caspius: TML row, TPC row, SG and TM 7, 8, 9 (all termed by Slater \& Wilcox 1973). The dark areas appear similar when observed under an optical microscope, but in fact, when observed under SEM, the fine structures differ greatly. TML row and TPC row belong to "cell" area; SG belongs to "network" area; and TM 7, 8, 9 belong to "protuberance and rugosity" area.

The position and number of "cell" areas are constant within a given species (but small "cell" areas may be lost in some individuals). It is usable in species diagnostics, however not in taxa at higher taxonomic levels. We did not observe the 
lower instars of I. caspius. However, we found that "cell" areas emerge from the 2nd instar in Iphicrates sp. (Lygaeoidea: Blissidae). All the species of Blissidae we observed have the celllike structure present on abdomen (unpublished data). This is unique among Lygaeoidea, even Heteroptera to our knowledge. So, we think that the uniqueness of this structure provides further support to giving this group family status (the hierarchical scheme of Henry 1997a). Slater \& Wilcox (1973) thought the cell-like areas (as TML row and TPC row) represent areas of muscle attachment. Further study should be done to validate the idea.

Ischnodemus Fieber is a common and widespread genus in Blissidae. The specimens of I. caspius were collected in the leaf sheaths of Phragmites sp. (from the collectors), and almost all of species of this genus live in the leaf sheaths of grasses (Slater 1976). The nymphs of most Blissidae have heavily sclerotized plates on the posterior abdominal segments. Slater (1976) presumed that these insects are able to move rapidly both backward and forward, and the plate-like terminal segment appear to be aid to the insects in moving backward deep into the leaf sheaths when disturbed. He also presumed that, for adaptive reasons, there is a tendency in Blissidae nymphs to develop sclerotized plates mesally on the dorsal surface of the abdomen, which are slightly raised above the general abdominal surface. The compact cuticular structure of terminal segment ("protuberance and rugosity" area) gives strongly support for this viewpoint.

The metathorax has been studied by numerous authors, including Johansson \& Braten (1970), Carayon (1971), Hepburn \& Yonke (1971), Schaefer (1972), Schuh (1984), Henry $(1997 b, c)$, and others. As far as we know, the modified cuticle of the evaporative area in adults can increase the defensive effectiveness of the glands, or, serve in restricting spread of scent fluids to a circumscribed area of the body (Schuh \& Slater 1995, Henry 1997b). The broad abdominal troughs function to direct secretions from the scent gland openings (Slater et al. 1977). In nymphs of $I$. caspius, dark plates surrounding scent gland openings are network-like structures, with irregular, rugosities and small papillae-like structures inside each cell. So we suggest that the specialized surfaces in nymphs may have a similar function to evaporative area in adults. But in some other groups of Lygaeoidea, such as Lygaeinae and Heterogastridae, each pair of orifices is surrounded by an extensive elliptic area with a smooth surface, which seems not to have such a function (unpublished data).

The head and pronotum of nymphs have only thick and sparse hairs, but in adults, they are dense, irregular, and have small hairs present in addition to the thick hairs. The basal and distal part of scutellum is strongly different in nymphs but very similar in adults. The structures of abdomen are very complicated in nymphs and can be divided to several types, but in adults, the cuticular morphology is simple and almost uniform. So, the cuticular structures of I. caspius go through great changes during the phase from the 5 th instar to the adult. As a whole, the cuticular morphology of nymphs is much more complicated than that of adults, especially the abdomen.

Acknowledgements. We express thanks to Ms. Gui-ling Pan for her help in producing the scanning electron microscope micrographs and to anonymous reviewers for valuable comments that improved the quality of the manuscript. We also thank Dr. Qiang Xie, Miss Yun Lü and Dr. Yun-ling Ke for their field collections. The project was supported by National Natural Sciences Foundation of China (No. 30570192) and the National Cultivation Project of Special Subjects in Basic Science (Insect Taxonomy, No. J0630963) of National Natural Science Foundation of China.

\section{References}

Baranowski, R. M. 1979: Note on the biology of Ischnodemus oblongus and I. fulvipes with descriptions of the immature stages (Hemiptera: Lygaeidae). - Ann. Ent. Soc. Amer. 72: 655-658.

Carayon, J. 1971: Note et documents sur l'appareil odorant métathoracique des Hémiptères. - Ann. Soc. Entomol. Fr. (new series) 7: 737-770.

Cassier, P., Nagnan, P. L. J. F., Andre, M. \& Guillaumin, D. 1994: Fine structure and physicochemical analysis of the nymphal and imaginal scent gland systems of Lincus spurcus (Rolston) (Heteroptera: Pentatomidae) Int. J. Ins. Morphol. Embryol. 23: 371-382.

Decker, G. C. \& Andre, F. 1938: Biological notes on Blissus iowensis Andre (Hemiptera-Lygaeidae). - Ann. Ent. Soc. Amer. 31: 457-466.

Henry, T. J. 1997a: Phylogenetic analysis of family groups within the infraorder Pentatomomorpha (Hemiptera: 
Heteroptera), with emphasis on the Lygaeoidea. Ann. Ent. Soc. Amer. 90: 275-301.

Henry, T. J. 1997b: Cladistic analysis and revision of the stilt bugs of the world (Heteroptera: Berytidae). Contrib. Am. Entomol. Inst. 30: 1-100.

Henry, T. J., 1997c: Monograph of the stilt bugs, or Berytidae (Heteroptera), of the Western Hemisphere. Mem. Entomol. Soc. Wash. 19: 1-149.

Hepburn, H. R. \& Yonke, Y. 1971: The metathoracic scent gland of coreoid Heteroptera. - J. Kans. Entomol. Soc. 44: 187-210.

Johansson, A. S. \& Braten, T. 1970: Cuticular morphology of the scent gland areas of some heteropterans. Entomol. Scand. 1: 158-162.

Péricart, J. 1998: Hémiptères Lygaeidae Euro-Méditerranéens. - Faune de France, 84 A: 1-468.

Putshkov, V. G. 1958: Larvae of Hemiptera-Heteroptera. I. Lygaeidae. - Rev. Ent. URSS 37: 392-413.

Rosa, J. A. da, Barata, J. M. S., Cilense, M. \& Belda Neto, F. M. 1999: Head morphology of $1^{\text {st }}$ and $5^{\text {th }}$ instar nymphs of Triatoma circummaculata and Triatoma rubrovaria (Hemiptera, Reduviidae). - Int. J. Ins. Morphol. Embryol. 28: 363-375.

Schaefer, C. W. 1972. Degree of metathoracic scent-gland development in the trichophorous Heteroptera (Hemiptera). - Ann. Ent. Soc. Amer. 65: 810-821.

Schuh, R. T. \& Slater, J. A. 1995: True bugs of the world (Hemiptera-Heteroptera). - Cornell Univ. Press, Ithaca, 336pp.

Schuh, R. T. 1984: Revision of the Phylinae (Hemiptera: Miridae) of Indo-Pacific. — Bull. Am. Mus. Nat. Hist. 177: $1-462$.

Slater, J. A. 1974: The genus Dimorphopterus (Hemiptera: Lygaeidae: Blissinae). — Trans. R. Entomol. Soc. Lond. 126: 57-89.
Slater, J. A. 1976: Monocots and chinch bugs: a study of host plants relationships in the lygaeid subfamily Blissinae (Hemiptera: Lygaeidae). — Biotropica 8: 143165.

Slater, J. A. 1987: The taxonomic status of Ischnodemus oblongus (Fabricius) and Ischnodemus variegatus (Signoret) (Hemiptera: Lygaeidae: Blissinae). — J. N. Y. Entomol. Soc. 95: 294-297.

Slater, J. A., Ashlock, P. D. \& Wilcox, D. B. 1969: The Blissinae of Thailand and Indochina. (Hemiptera: Lygaeidae). - Pac. Insect 11: 671-733.

Slater, J. A. \& Brailovsky, H. 1983: Review of the Neotropical genus Toonglasa (Hemiptera: Lygaeidae). Ann. Ent. Soc. Amer. 76: 523-535.

Slater, J. A. \& Brailovsky, H. 1986: A new species of Riggiella Kormilev from Mexico (Hemiptera: Lygaeidae: Blissinae). - Proc. Entomol. Soc. Wash. 88: 8-12.

Slater, J. A. \& Brailovsky, H. 1990: A further contribution to the systematics of the genus Toonglasa (Hemiptera: Lygaeidae: Blissinae). — J. N. Y. Entomol. Soc. 98: 406-423.

Slater, J. A. \& Harrington, J. E. 1970: A revision of the genus Ischnodemus Fieber in the Ethiopian (Hemiptera: Lygaeidae, Blissinae). — Ann. Trans. Mus. 26: 211 275.

Slater, J. A., Sweet, M. H. \& Baranowski, R. M. 1977: The systematics and biology of the genus Bathydema Uhler (Hemiptera: Lygaeidae). — Ann. Ent. Soc. Amer. 70: 343-358.

Slater, J. A. \& Wilcox, D. B. 1973: The chinch bugs or Blissinae of South Africa (Hemiptera: Lygaeidae). Mem. Entomol. Soc. South. Afr. 12: 1-135. 